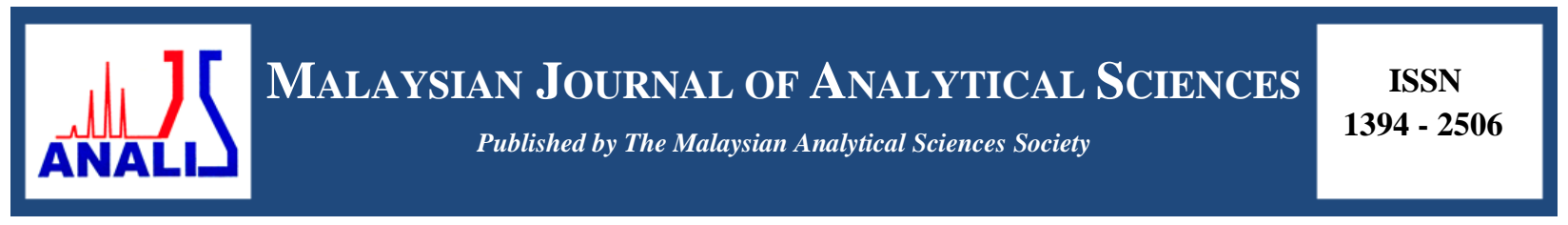

\title{
POTENTIAL OF CABBAGE EXTRACT (Brassica oleracea) AS ANTI- FOULING AGENT IN ALKYD UNDERCOAT FOR MILD STEEL IN SEAWATER
}

\author{
(Potensi Ekstrak Kubis (Brassica oleracea) Sebagai Ejen Anti-Kotoran bagi Cat Asas Alkid \\ untuk Keluli Lembut di dalam Air Laut)
}

\author{
Mohammad Fakhratul Ridwan Zulkifli ${ }^{1}$, Norasidayu Mohd Radzi ${ }^{1}$, Suriani Mat Jusoh ${ }^{1}$,Jasnizat Saidin ${ }^{2}$, \\ Wan Mohd Norsani Wan $\mathrm{Nik}^{1 *}$ \\ ${ }^{1}$ School of Ocean Engineering \\ ${ }^{2}$ Institute of Marine Biotechnology \\ Universiti Malaysia Terengganu, 21030 Kuala Nerus, Terengganu, Malaysia \\ *Corresponding author: niksani@umt.edu.my
}

Received: 1 January 2019; Accepted: 22 May 2019

\begin{abstract}
An investigation was conducted on cabbage extract (Brassica oleracea) to observe its function as green antifouling agent in alkyd undercoat for mild steel in seawater. Cabbage extract shows $43.6 \%$ of inhibition efficiency towards Pseudomonas aeruginosa bacteria at $15.525 \mathrm{~g} / \mathrm{mL}$ cabbage concentration. FTIR analysis shows the complexation between alkyd paint and cabbage extract where the peak in $\mathrm{OH}, \mathrm{C}-\mathrm{H}$ and $\mathrm{C}=\mathrm{O}$ have shifted indicating the chain scission of the alkyd resin polymer backbone with cabbage extract. Weight gained analysis reveals that coated mild steel incorporated with cabbage extract had reduced the fouling attachment. However, weight gained value increases as the immersion period increases for all coated samples. Morphological profile of coated mild steel shows an attachment of fouling where prominent attachment can be observed on coated mild steel without cabbage extract.
\end{abstract}

Keywords: anti-fouling, alkyd undercoat, Brassica oleracea, Pseudomonas aeruginosa, mild steel

\section{Abstrak}

Kajian telah dilaksanakan terhadap ekstrak kubis untuk melihat fungsinya sebagai ejen anti-kotoran hijau di dalam cat asas alkid untuk keluli lembut di dalam air laut. Ekstrak kubis menunjukkan sebanyak $43.6 \%$ kecekapan perencatan terhadap bakteria Pseudomonas aeruginosa pada ekstrak kubis berkepekatan $15.525 \mathrm{~g} / \mathrm{mL}$. Analisis FTIR menunjukkan pengkompleksan antara pelitup cat asas alkid dan ekstrak kubis di mana puncak $\mathrm{OH}, \mathrm{C}-\mathrm{H}$ dan $\mathrm{C}=\mathrm{O}$ telah berubah menandakan berlaku tindakbalas guntingan pada rantai utama polimer resin alkid yang mengandungi ekstrak kubis. Analisis pertambahan berat menunjukkan keluli lembut bersadur yang mengandungi ekstrak kubis telah mengurangkan kelekatan kotoran. Walaubagaimanapun, nilai pertambahan berat telah meningkat apabila tempoh rendaman meningkat untuk kesemua sampel bersadur. Profil morfologi keluli lembut bersadur menunjukkan perlekatan kotoran di mana perlekatan ini lebih jelas kelihatan pada keluli lembut bersadur tanpa gabungan ekstrak kubis.

Kata kunci: anti-kotoran, cat asas alkid, Brassica oleracea, Pseudomonas aeruginosa, keluli lembut 


\section{Introduction}

Mild steel is vastly used in industrial application to build bridges, building and other structures including different types of machine parts [1]. Mild steel is low in cost and therefore it is relatively high in demand for this steel especially in maritime industry. Mild steel possesses enough strength despite its low carbon content. Besides, mild steel can be molded into any required shape and was known as one of the most versatile materials as it can be formed into various shapes.

However, growth of marine organism like barnacle, seaweed and bio-fouling is one of the paramount problems resulting in poor performance of the materials. One of the methods to avoid biofouling is by using antifouling coating based on organotin compounds such as tributyltin (TBT) and triphenyltin. However, organotin are not environmental-friendly as it is not readily degradable and are toxic to the environment. Hence, Internal Maritime Organization (IMO) prohibits the application of TBT in ships, effective on 17 September 2008 [2].

Therefore, development of environmentally antifoul coating to protect mild steel against marine organism attachment and fouling is utmost important. The potential of cabbage (brassica oleracea) as an eco-friendly antifouling for mild steel in seawater was then investigated. To achieve the objective, few methods were used in this study including crystal violet anti biofilm assay, weight measurements and scanning by electron microscope.

\section{Surface preparation of mild steel}

\section{Materials and Methods}

Mild steel grade JR235 (25mm x $25 \mathrm{~mm}$ x $4 \mathrm{~mm})$ was cut into square shape and polished using copper brush to remove any loose rust or loose mill scales. Then the samples were soaked in thinner and wiped with a wet cloth to free its surface from any oil or dirt. Then it was rinsed with distilled water in accordance to ASTM D $2651-01$ standard. The specimens were then stored in a desiccator prior to use.

\section{Extraction of cabbage}

Cabbages were purchased from the local supermarkets and cut into small pieces. Moisture in cabbages was removed through refrigeration at $-80^{\circ} \mathrm{C}$ for 24 hours. Then, it was transferred to a vacuum refrigerator with a temperature set at $-40{ }^{\circ} \mathrm{C}$ in order to evaporate any frozen water in the plastic. Once the cabbage was dried, it was crushed into powder form. Then, the cabbage powder was immersed in $500 \mathrm{~mL}$ of methanol and soaked in a sonicator to accelerate the extraction. Finally, the rotary evaporator (rotavapor) was used to remove the solvents from samples.

\section{Preparation of coating}

MCI Paint Blue-I Undercoat (White) was used as an undercoating and it is suitable to be used under several conditions [3]. Four different weights of cabbage that are $2 \mathrm{~g}, 4 \mathrm{~g}, 6 \mathrm{~g}$, and $8 \mathrm{~g}$ were incorporated in the coating. The modified coating was stirred for several hours. The specimens were coated using dip coating method. The thickness of the coating allowed for this paint is in the range of 80 to 120 microns which was measured by using PosiTector 6000 thickness gauge.

\section{Antifouling crystal violet anti-biofilm assay}

Pseudomonas aeruginosa used in this study is a type of marine bacteria that can grow in seawater as it has a very simple nutritional requirement. Muller Himpton Brooth and Muller Himpton Agar were prepared. The prepared bacteria, nutrient broth, sample of cabbage extract were then pipetted inside the 96 wells of microtiter plate and transferred into an incubator for 24 hours to allow the biofilms to grow. The optical density (OD) of bacteria liquid culture was determined and the reading must be less than $0.2 \mathrm{OD}$. After 24 hours of incubation at $37^{\circ} \mathrm{C}$, the medium was gently removed and placed in the oven at $60^{\circ} \mathrm{C}$ for it to dry. The microtiter plate well was stained with $200 \mu \mathrm{L}$ of $1 \%$ of crystal violet for 20 minutes at room temperature. The unbound crystal violet stain was removed and the well was gently washed three times with $200 \mu \mathrm{L}$ distilled water without touching the well's wall. The wells then were air-dried for 15 minutes and the crystal violet in each well was solubilized by adding $200 \mu \mathrm{L}$ of $75 \%$ alcohol and incubated at room temperature for 10 minutes in the shaker. The motion plate was read at $492 \mathrm{~nm}$ by using ELISA reader. The data was analysed using equation 1.

$$
\text { Inhibition efficiency }(\%)=\frac{(\text { OD Negative control-OD Sample })}{\text { OD Negative control }} \times 100
$$




\section{Immersion test}

The immersion test was conducted at Merang Jetty, Terengganu. The samples were hung in a cage and sunk into the seabed below the jetty for 75 days as shown in Figure 1. The results were taken every 15 days and the weight changes were observed.
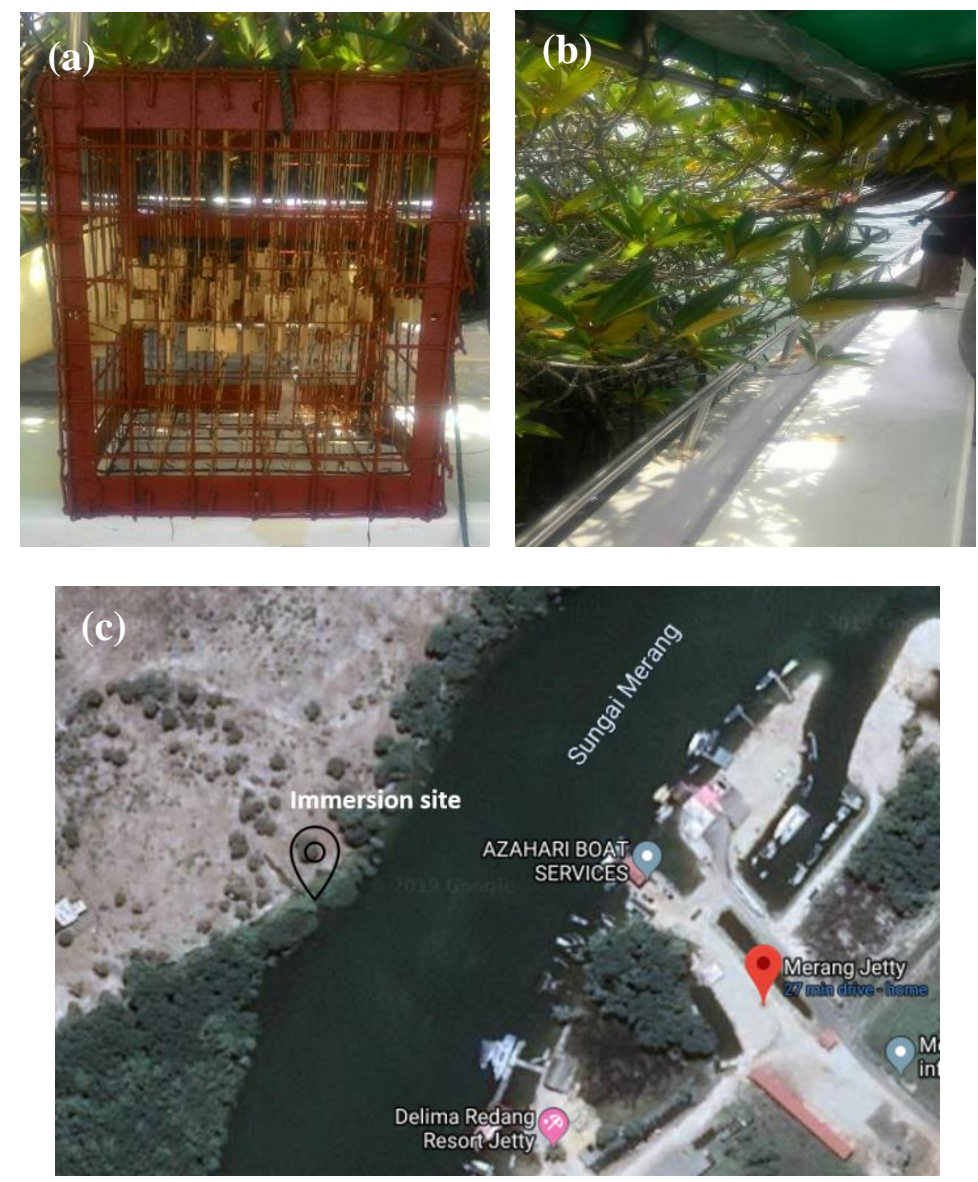

Figure 1. (a) Cage used as the sample holder, (b) Immersion took place at mangrove area and (c) Location of the immersion area

\section{Fourier transform infrared}

Fourier transform infrared (FTIR) was carried out using Thermo Nicolet 380 FTIR Spectrometer. The sample was placed on germanium crystal and passed through infrared light with the frequency ranging from $3960-660 \mathrm{~cm}^{-1}$ with spectral resolution of $4 \mathrm{~cm}^{-1}$ [4]. FTIR data were recorded in transmittance mode. The spectral pattern was analysed and matched according to IR absorption table.

\section{Weight loss method}

The process started by recording the initial weight of the mild steel specimen after it was coated with alkyd paints with and without cabbage extract. The plates were weighed every 15 days and the data were recorded. As part of the analysis procedure, the weight of these plates were re-measured after each immersion time interval. Equation 2 was used to calculate the percentage of the weight gained while Equation 3 was used to determine anti-fouling efficiencies. 


$$
\begin{aligned}
& \text { Weight gain }(\%)=\frac{\text { final weight-initial weight }}{\text { total weight }} \times 100 \\
& \text { Anti fouling efficiency }(\%)=\frac{\text { weight gained }_{0}-\text { weight gained }_{1}}{\text { weight gained }_{0}} \times 100
\end{aligned}
$$

where weight gained ${ }_{0}$ is the weight gained percentage of coated samples without cabbage extract and weight gained is the weight gained percentage of coated samples with cabbage extract.

\section{Scanning electron microscopy}

Scanning electron microscope (SEM) model JEOL JSM-6360LA was used in this study to observe and analyses the morphology of coated mild steel. The samples were subjected to coating process with an ultrathin gold particle layer using JFC-1600 Auto Fine Coater (JEOL Ltd., Tokyo, Japan). The gold coated samples being electrically conductive allows for scanning process on the sample surface at an accelerated voltage of $15 \mathrm{kV}$ and a working distance of $10 \mathrm{~mm}$.

\section{Optical density}

\section{Results and Discussion}

Pseudomonas aeruginosa was pipetted in 96 well plates. The percentage reading of inhibition efficiency for dilution test of antifouling crystal violet anti-biofilm assay was calculated using equation 1 . From Table 1, the reading of OD negative control is greater than the value of OD sample.

Table 1. Inhibition efficiency of cabbage extract at various concentrations

\begin{tabular}{lcc}
\hline $\begin{array}{l}\text { Concentration of Cabbage } \\
\text { (g/ml) }\end{array}$ & $\begin{array}{c}\text { Optical Density } \\
\text { of Cabbage Sample }\end{array}$ & $\begin{array}{c}\text { Inhibition Efficiency } \\
(\mathbf{\%})\end{array}$ \\
\hline 15.525 & 1.737 & 43.6 \\
7.763 & 1.864 & 39.5 \\
3.881 & 2.067 & 32.9 \\
1.941 & 2.212 & 28.2 \\
0.970 & 2.334 & 24.2 \\
0.485 & 2.449 & 20.5 \\
0.243 & 2.928 & 4.9 \\
OD negative & 3.080 & \\
\hline
\end{tabular}

Figure 2 shows the dilution test plot of the cabbage extracts towards the target bacteria of Pseudomonas aeruginosa. As the concentration of cabbage extract increases, the ability to inhibit the formation of biofilm also increases. Generally, plants are known to have natural fouling inhibition effect against Gram-negative and Gram-positive bacteria [5]. The bacteria used in this test were Pseudomonas aeruginosa, a type of Gram-negative bacteria. The activity against this type of bacteria indicated the presence of broad-spectrum antibiotic compounds or simply any general metabolic toxins. The antimicrobial efficiency of components in plants depends on the chemical structure of active components and the concentration used. Some of the chemical components present in plants giving antimicrobial characteristics that include thiosulfinates, saponin, flavonoids, phenolic, organic acids, and glucosinolates [6]. The phenolic compound such as terpenes, aliphatic alcohol, aldehydes, ketones, acids and isoflavonoids are the main components in plants that have antimicrobial activity [7]. 


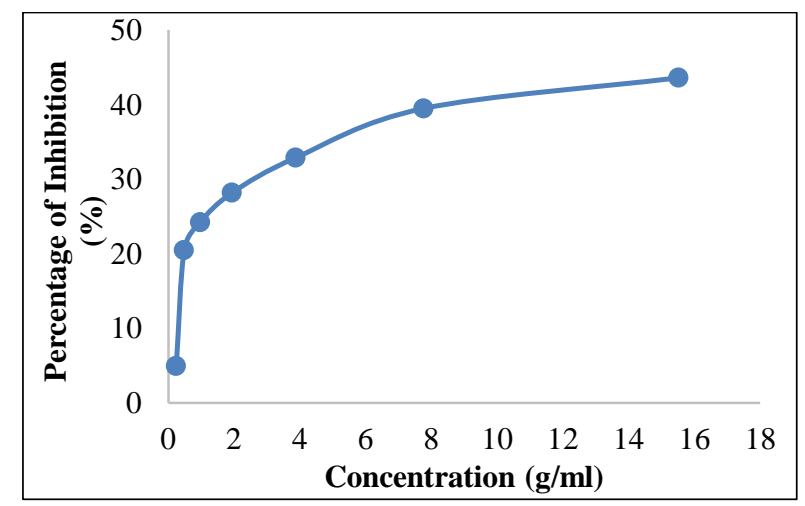

Figure 2. Percentage of inhibition efficiency of cabbage extract towards targeted bacteria (Pseudomonas aeruginosa)

Fouling inhibition effect of cabbage is strongly influenced by its active ingredient known as phenolic compounds. This compound is well known as anti-microbial agent that either kills microorganisms or suppresses their growth. The antimicrobial activity of phenolic compounds is to alter microbial cell permeability, hence enable the loss of macromolecules from the cell interior [6,8]. The cabbage showed anti-microbial activity against Pseudomonas aeruginosa due to the presence of the phenolic compound.

\section{Fourier transform infrared}

FTIR spectrum was used to identify the functional groups of the active components present in cabbage extract, alkyd paint and the modified alkyd paint based on the peak values in the recorded spectrum. The FTIR spectrum of cabbage extract is shown in Figure 3. The absorption band at $3368.06 \mathrm{~cm}^{-1}$ can be attributed to the $\mathrm{O}-\mathrm{H}$ stretching in alcohol group while another peak at $2937.04 \mathrm{~cm}^{-1}$ can be assigned to $\mathrm{C}-\mathrm{H}$ stretching for alkenes. The peak obtained at $2106.99 \mathrm{~cm}^{-1}$ showed the presence of $\mathrm{C} \equiv \mathrm{C}$ stretching representing the alkynes compound. Broad absorption at $1638.01 \mathrm{~cm}^{-1}$ indicates the presence of N-H bending while at $1412.11 \mathrm{~cm}^{-1}$ revealed the presence of C-C stretching (aromatic ring). The functional group of alcohol, carboxylic acid, ester, and ethers were found at peak value of $1059.80 \mathrm{~cm}^{-1}$ (C-O stretching). Cabbage showed infrared absorbance characteristics of carboxylic acid $(\mathrm{O}-\mathrm{H})$ at the peak of $919.93 \mathrm{~cm}^{-1}$. The functional alkenes group $(=\mathrm{C}-\mathrm{H})$ was also found in the cabbage at the peak of $866.76 \mathrm{~cm}^{-1}$. Other functional group found were C-CL stretching, alkyl halides at the peak of $818.67 \mathrm{~cm}^{-1}$. The phenolic compound was characterised as having at least one aromatic ring with one or more hydroxyl groups attached to it [9].

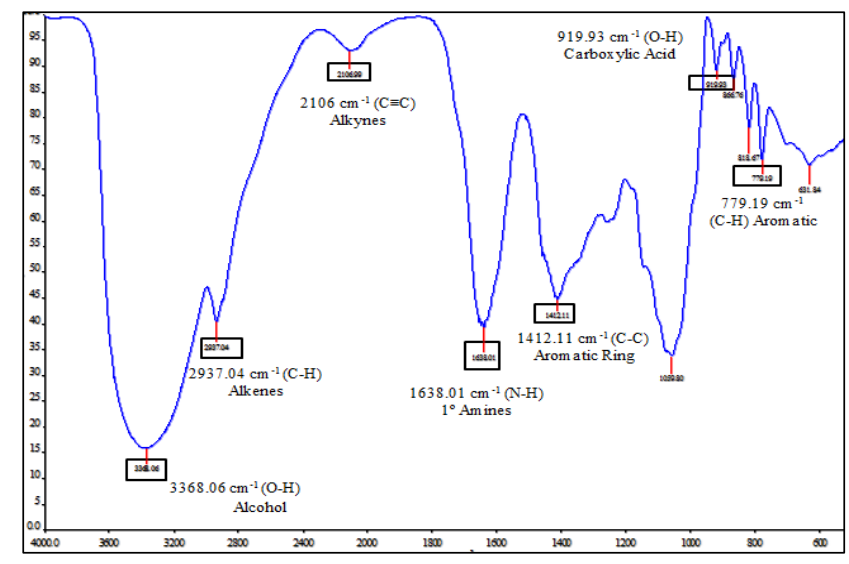

Figure 3. FTIR spectrum for cabbage extract 
FTIR spectrum of alkyd undercoat is shown in Figure 4. C-H stretching alkenes is found at $2926.63 \mathrm{~cm}^{-1}, 1735.12$ $\mathrm{cm}^{-1}$ indicating the presence of stretching $\mathrm{C}=\mathrm{O}$ while $\mathrm{C}-\mathrm{C}$ and $\mathrm{C}-\mathrm{H}$ aromatics were found at $1417.05 \mathrm{~cm}^{-1}$ and $743.49 \mathrm{~cm}^{-1}$.

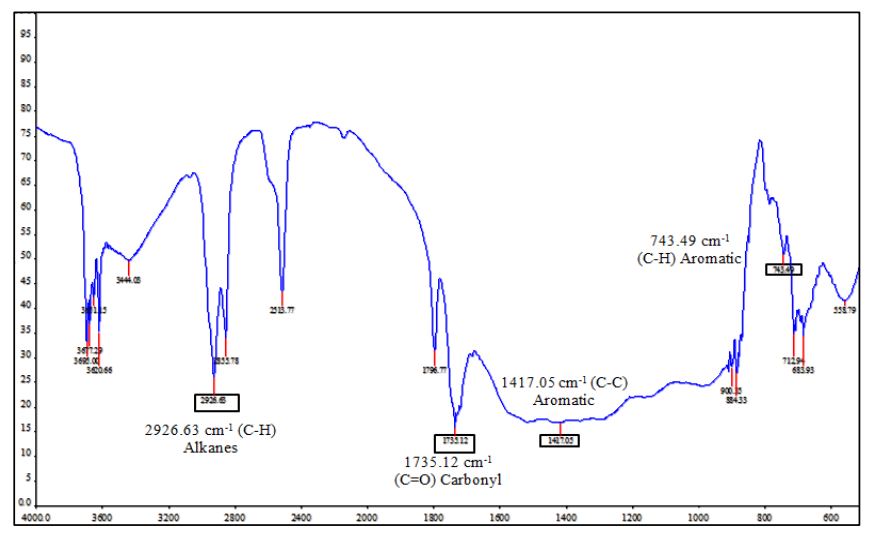

Figure 4. FTIR spectrum for alkyd undercoat

Figure 5 shows the spectrum profile of alkyd undercoat with the incorporation of cabbage extract. A broad band of stretching $\mathrm{OH}$ shifted from 3368.06 to $3319.93 \mathrm{~cm}^{-1}$ due to alkyd resin polymer backbone dissociate while cabbage extract has been associated in the polymer to form a complexation. C-H stretching in medium intensity was shifted from 2937.04 to $2927.33 \mathrm{~cm}^{-1}$ while a strong intensity band of carbonyl shifted from 1727.25 to $1735.12 \mathrm{~cm}^{-1}$ due to chain scission of alkyd undercoat polymer that allows reaction with other molecules.

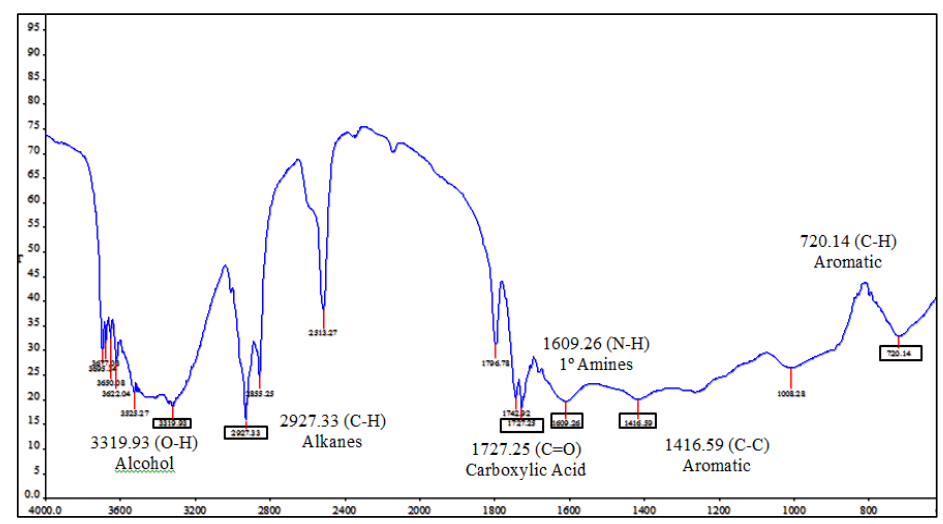

Figure 5. FTIR spectrum graph for alkyd undercoat incorporated with cabbage extract

\section{Weight measurement}

Table 2 shows the percentage data of additional weight for all tested samples. The coated samples without any cabbage loading show the highest percentage in weight gain. Sample with the highest concentration of cabbage $(0.20 \mathrm{~g} / \mathrm{mL})$ shows the least percentage in additional weight for the entire period of immersion. Figure 6 shows the percentage of additional weight for each sample with different cabbage concentration relative to its immersion period. Upon addition of cabbage extract in alkyd undercoat, the weight gain of the coated samples was reduced and the efficiency increases. As the concentration of cabbage extract increases, the value of weight gain was found to decrease and the efficiency increases. However, as the immersion period increases, weight gains were also increased for all coated samples which consequently reduce its anti-fouling efficiency. 
Table 2. Weight measurement data for different concentration of cabbage

\begin{tabular}{|c|c|c|c|c|c|c|}
\hline $\begin{array}{l}\text { Sample } \\
\text { concentration } \\
\text { (g/ml) }\end{array}$ & Days & $\begin{array}{l}\text { Initial weight } \\
\text { (g) }\end{array}$ & $\begin{array}{l}\text { Final weight } \\
\text { (g) }\end{array}$ & $\begin{array}{c}\text { Total weight } \\
\text { (g) }\end{array}$ & $\begin{array}{c}\text { Additional weight } \\
(\%)\end{array}$ & $\begin{array}{c}\text { Anti-fouling } \\
\text { efficiency } \\
(\%)\end{array}$ \\
\hline \multirow{5}{*}{0.00} & 15 & 14.85 & 14.878 & 29.756 & 0.094 & - \\
\hline & 30 & 14.409 & 14.611 & 29.222 & 0.691 & - \\
\hline & 45 & 14.148 & 14.475 & 28.95 & 1.13 & - \\
\hline & 60 & 14.698 & 15.173 & 30.346 & 1.565 & - \\
\hline & 75 & 14.543 & 15.057 & 30.114 & 1.707 & - \\
\hline \multirow{5}{*}{0.05} & 15 & 14.978 & 15.001 & 30.002 & 0.077 & 18 \\
\hline & 30 & 14.694 & 14.859 & 29.718 & 0.555 & 20 \\
\hline & 45 & 14.686 & 15.001 & 30.002 & 1.05 & 7 \\
\hline & 60 & 14.783 & 15.216 & 30.432 & 1.424 & 9 \\
\hline & 75 & 14.682 & 15.15 & 30.3 & 1.543 & 10 \\
\hline \multirow{5}{*}{0.10} & 15 & 14.712 & 14.729 & 29.458 & 0.058 & 38 \\
\hline & 30 & 14.617 & 14.742 & 29.484 & 0.424 & 39 \\
\hline & 45 & 14.577 & 14.817 & 29.634 & 0.81 & 28 \\
\hline & 60 & 14.73 & 15.076 & 30.151 & 1.148 & 27 \\
\hline & 75 & 14.513 & 14.912 & 29.823 & 1.336 & 22 \\
\hline \multirow{5}{*}{0.15} & 15 & 14.848 & 14.856 & 29.712 & 0.027 & 71 \\
\hline & 30 & 14.782 & 14.865 & 29.73 & 0.279 & 60 \\
\hline & 45 & 14.47 & 14.634 & 29.268 & 0.56 & 50 \\
\hline & 60 & 14.836 & 15.078 & 30.157 & 0.803 & 49 \\
\hline & 75 & 14.634 & 14.942 & 29.884 & 1.03 & 40 \\
\hline \multirow{5}{*}{0.20} & 15 & 15.098 & 15.1 & 30.2 & 0.007 & 93 \\
\hline & 30 & 14.813 & 14.855 & 29.71 & 0.142 & 79 \\
\hline & 45 & 14.755 & 14.84 & 29.68 & 0.285 & 75 \\
\hline & 60 & 14.998 & 15.167 & 30.333 & 0.555 & 65 \\
\hline & 75 & 14.872 & 15.076 & 30.152 & 0.675 & 60 \\
\hline
\end{tabular}

The fouling process involves three main stages known as the formation of conditioning film, micro-fouling and macro-fouling [10]. During conditioning film phase, organic molecules in the water attached to the surface of the immersed object and within minutes intensify their activity for further attachment. During the second phase (microfouling), the combination of conditioning film and dead bacteria cells generates the first stage of micro fouling. Then the macro-algae, diatoms colonies and protozoa spore's attachment increase the micro-fouling extent within the first two to three weeks, generating the second film layer. Lastly, the final stage is when the micro-fouling encourages the attachment of algae, animal larvae and spores, and followed by the settlement of a mature marine organism, the process which is called macro-fouling [10]. 


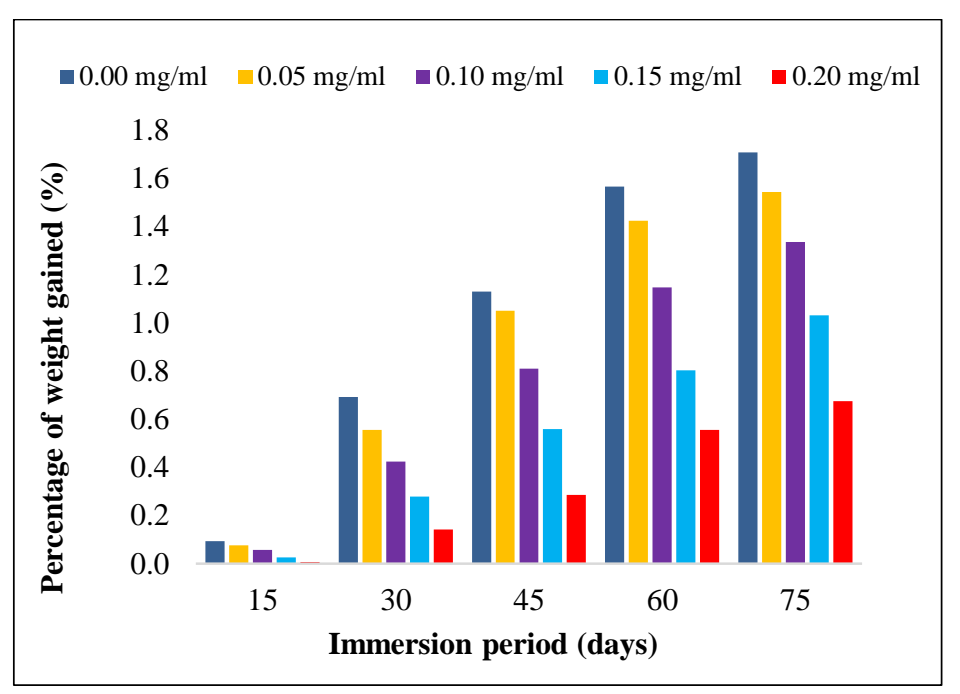

Figure 6. Percentage of weight gain by different concentration of cabbage extract

Cabbage extract contains a compound known as phenolic compound. Phenolic compound was usually derived from natural sources such as plants foods such as fruits, cereal grain, and vegetables that have antifungal properties. The most common phenolic compounds are phenolic acids, flavonoids, and lignin [11]. Phenolic acids affect the cell membrane of Gram-positive and Gram-negative bacteria and lead to a change in cell surface hydrophobicity and charge which ultimately cause leakage of cytoplasmic content [12]. Figure 7 shows how the phenolic compound in the cabbage extract reacted to the organism in the water by inhibiting the microorganism from attaching at the mild steel surface. The hydroxyl group attached to the benzene ring (phenolic compound) interrupts the formation of conditioning film (the first step of fouling process) on the metal surface and repels the attachment of organism in seawater with the present of $\mathrm{OH}^{-}$in the modified paint.

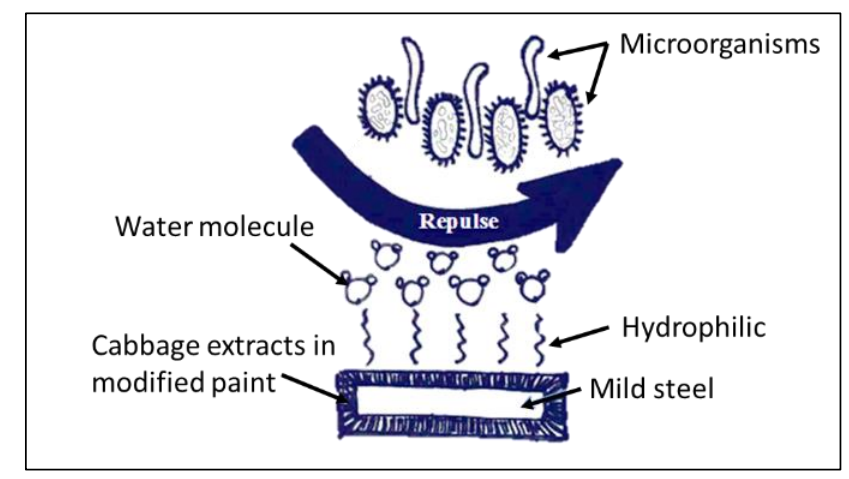

Figure 7. The mechanism of antimicrobial function in cabbage

\section{Scanning electron microscope}

The morphology profile of coated samples is shown in Table 3. The attachment and formation of the fouling organism on the surface of mild steel can be observed. The cabbage which acts as an inhibitor was chemically absorbed on the surface of the metal and formed a protective thin film with inhibitor effect [13]. Based on the camera image in Figure 8, there are many fouling organisms formed at the surface of coated mild steel without incorporation of cabbage extract. Figure 9 shows an image of coated mild steel with the highest concentration of cabbage extract $(0.20 \mathrm{mg} / \mathrm{mL})$. At this stage, the least amount of fouling attachment can be seen. 
Table 3. SEM and camera image after 75 days of immersion test at Merang Jetty

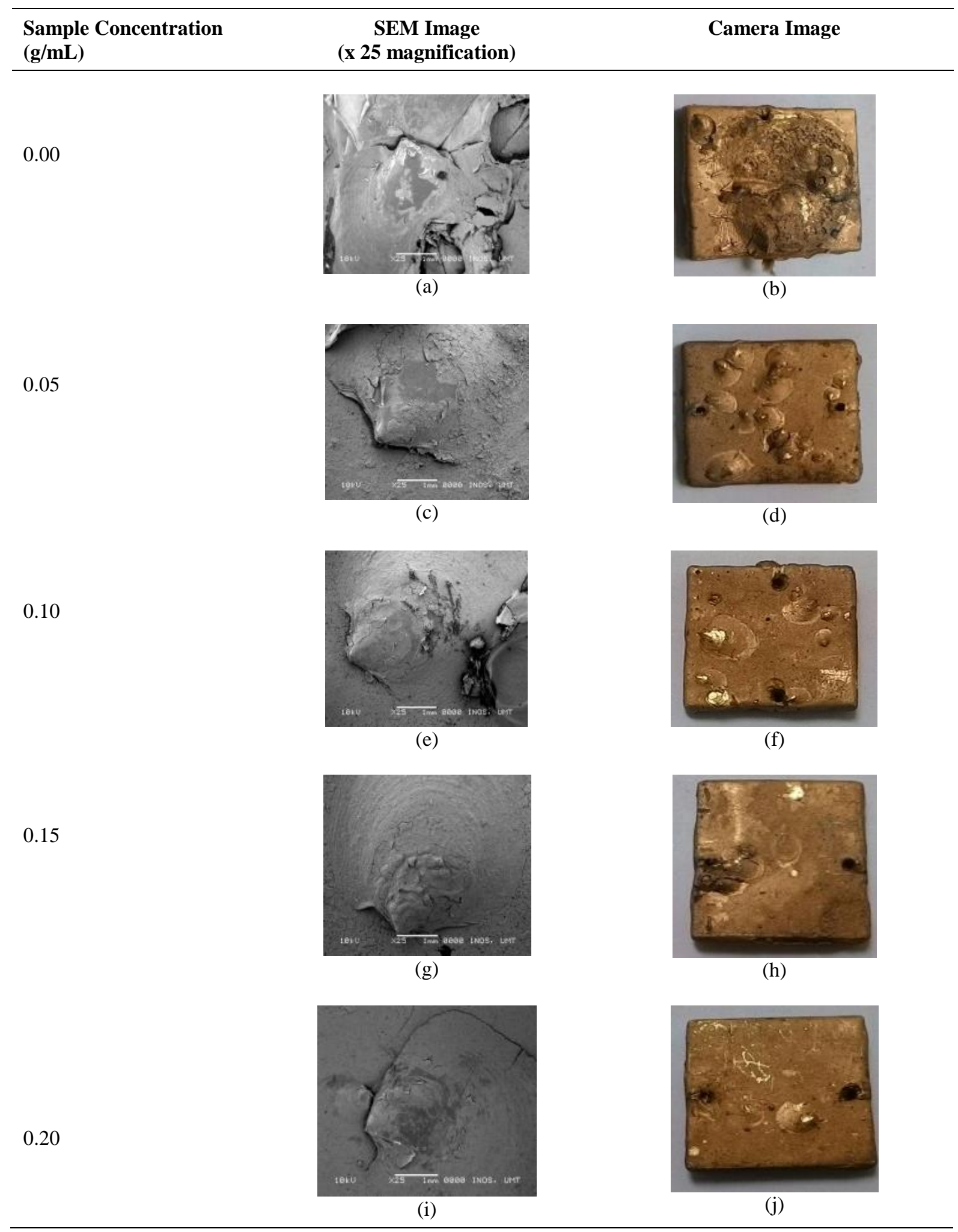



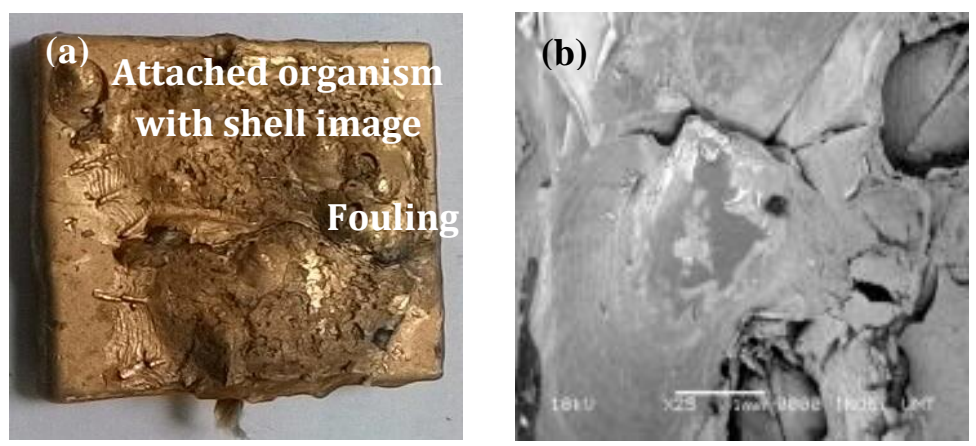

Figure 8. (a) Camera image and (b) SEM image of 25 times magnification after immersion test for $0.00 \mathrm{mg} / \mathrm{mL}$ concentration
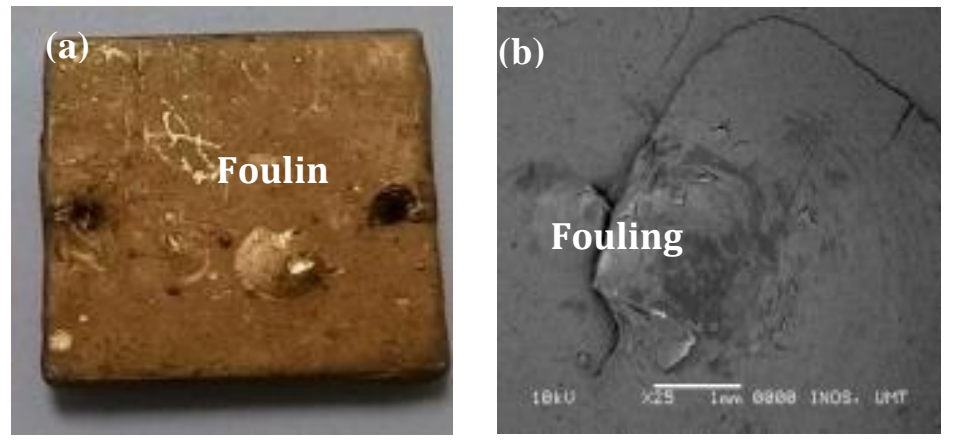

Figure 9. (a) Camera image and b) SEM image of 25 times magnification after immersion test for $0.20 \mathrm{mg} / \mathrm{mL}$ concentration

The amount of fouling attached on the surface of mild steel for all coated samples is tabulated in Table 3 . Visual observation shows that the fouling attachment is decreasing as the concentration of cabbage extract increases. It can be inferred that the incorporation of cabbage extract increases the anti-fouling properties of the alkyd undercoat. According to the suggested mechanism previously discussed, cabbage extract has the potential to be an anti-fouling agent in alkyd paint.

\section{Conclusion}

Crystal violet anti-biofilm assay and weight measurement prove that cabbage has a good antifouling properties and performance. Anti-fouling efficiency increases as the cabbage extract concentration is increased but decreases in longer immersion period. FTIR analysis shows that there is complexation reaction between alkyd undercoat and cabbage extract that contributes to the anti-fouling performance of the modified alkyd undercoat. The results show that cabbage extract has the ability to inhibit the growth of fouling for immersed metal surface even with low concentration of the extract. Therefore, it is inferred that cabbage extract as a natural product has a potential as an additive in paint to reduce fouling settlement on the coated mild steel.

\section{Acknowledgement}

The author would like to thank laboratory staff of Maritime Technology, School of Ocean Engineering and Institute of Marine Biotechnology for their assistance and Ministry of Higher Education for the look east policy grant (53168).

\section{References}

1. Finšgar, M. and Jackson, J. (2014). Application of corrosion inhibitors for steels in acidic media for the oil and gas industry: A review. Corrosion Science, 86: 17-41. 
2. Qian, P. Y., Xu, Y. and Fusetani, N. (2009). Natural products as antifouling compounds: recent progress and future perspectives. Biofouling, 26(2): 223-234.

3. Abdullah, S. H. (2012). Antifouling potential of mangrove bark condensed tannins (Rhizophora apiculata) as antifouling for mild steel in seawater. Thesis of Bachelor Degree, Universiti Malaysia Terengganu.

4. Samsudin, A. S., Khairul, W. M., and Isa, M. I. N. (2012). Characterization on the potential of carboxy methylcellulose for application as proton conducting biopolymer electrolytes. Journal of Non-Crystalline Solids, 358: 1104-1112.

5. Yayan, J., Ghebremedhin, B. and Rasche, K. (2015). Antibiotic resistance of Pseudomonas aeruginosa in pneumonia at a single university hospital center in Germany over a 10-year period. PLOS one, 10(10): 1-20.

6. Hayek, S. A. and Ibrahim, S. A. (2013). Current limitations and challenges with lactic acid bacteria: A review. Food and Nutrition Sciences, 4(11): 73-87.

7. Tiwari, B. K., Valdramidis, V. P., O'Donnell, C. P., Muthukumarappan, K., Bourke, P. and Cullen, P. J. (2009). Application of natural antimicrobials for food preservation. Journal of Agricultural and Food Chemistry, 57(14): 5987-6000.

8. Bajpai, V. K., Rahman, A., Dung, N. T., Huh, M. K., and Kang, S. C. (2008). In vitro inhibition of food spoilage and foodborne pathogenic bacteria by essential oil and leaf extracts of Magnolia liliflora Desr. Journal of Food Science, 73(6): 314-320.

9. Balasundram, N., Sundram, K. and Samman, S. (2006). Phenolic compounds in plants and agri-industrial byproducts: Antioxidant activity, occurrence, and potential uses. Food Chemistry, 99(1): 191-203.

10. Nurioglu, A. G., and Esteves, A. C. C. (2015). Non-toxic, non-biocide-release antifouling coatings based on molecular structure design for marine applications. Journal of Materials Chemistry B, 3(32): 6547- 6570.

11. Teodoro, G. R., Ellepola, K., Seneviratne, C. J. and Koga-Ito, C. Y. (2015). Potential use of phenolic acids as anti-Candida agents: a review. Frontiers in Microbiology, 6: 1420.

12. Cho, J. Y., Kwon, E. H., Choi, J. S., Hong, S. Y., Shin, H. W. and Hong, Y. K. (2001). Antifouling activity of seaweed extracts on the green alga Enteromorpha prolifera and the mussel Mytilus edulis. Journal of Applied Phycology, 13(2): 117-125.

13. Dariva, C. G. and Galio, A. F. (2014). Corrosion inhibitors-principles, mechanisms and applications. In developments in corrosion protection. InTech Open Publisher. 